\section{Cientistas, visitantes e guias nativos na construção das representações de ciência e paisagem na Floresta Nacional de Caxiuanã}

\author{
Maria das Graças Ferraz Bezerra \\ Analista em Ciência e Tecnologia \\ Museu Paraense Emílio Goeldi \\ grerraz@museu-goeldi.br \\ Tese de Doutorado \\ Programa de Pós-Graduação em Ciências Sociais \\ Universidade Federal do Pará / Museu Paraense Emílio Goeldi \\ Belém (PA) 2008
}

O estudo analisa o processo de produção do conhecimento científico, tendo como contraponto o conhecimento tradicional e as inter-relações entre cientistas e guias de campo nativos na Floresta Nacional de Caxiuanã, no Município de Melgaço (PA), Brasil, onde o Museu Paraense Emílio Goeldi mantém uma base de pesquisas científicas aberta a pesquisadores brasileiros e estrangeiros. A análise leva em consideração tanto o ambiente onde os guias de campo trabalham como a estrutura acadêmica em que se inserem os pesquisadores.

\section{Scientists, visitors and native guides in the production of science and landscape representations at Caxiuanã National Forest, Pará, Brazil}

\author{
Maria das Graças Ferraz Bezerra \\ S\&T Analyst \\ Emílio Goeldi Museum of Pará \\ grerraz@museu-goeldi.br \\ Doctoral Thesis \\ Pos-Graduation Program in Social Sciences \\ Federal University of Pará / Emílio Goeldi Museum of Pará \\ Belém (PA) - Brazil 2008
}

The thesis analyses the process of scientific knowledge production in a traditional settlement at Caxiuanã National Forest, in Melgaço, Pará, Amazon, Brazil, where the Goeldi Museum maintains a scientific basis open for Brazilian and International researchers. The focus is on the relationship between scientists and native field guides, considering both the environment where they work and the given academic system. 